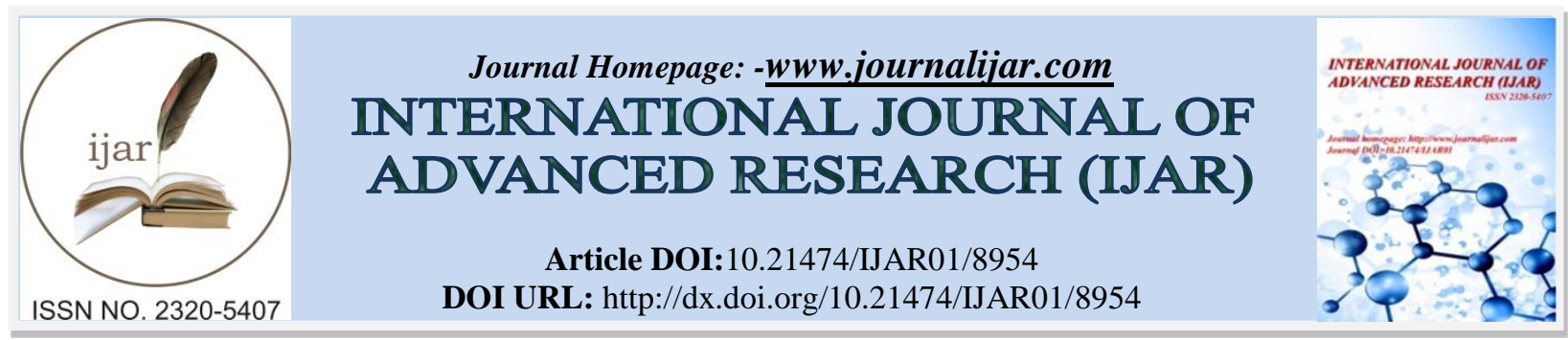

RESEARCH ARTICLE

\title{
LITERARY STYLISTIC DEVICES IN SIKHEBO AS AN ACCULTURATIVE DRAMATIC NARRATIVE OF BABUKUSU OF BUNGOMA COUNTY, KENYA.
}

Paul Wanyonyi Khaemba, Kitche Magak and Jane Bwonya.

Maseno University, P. O. Box P.O. Box 3275-40100, Kisumu, Kenya.

\section{Manuscript Info}

Manuscript History

Received: 22 February 2019

Final Accepted: 24 March 2019

Published: April 2019

Key words:-

Literary Stylistic Devices, Acculturative

Dramatic Narrative, Sikhebo Ritual,

Babukusu, Kenya.

\begin{abstract}
Babukusu community in Bungoma County in Kenya initiate boys into adulthood after every two years through a ceremony called sikhebo. The ritual involves literary stylistic devices that aid in the development of drama as well as transmit societal values and ideals to community members. The study adopted Literary Functionalism as a theoretical framework. This paper discusses literary stylistic devices in sikhebo as an acculturative dramatic narrative in the entire process of sikhebo, including preparation stage, ritual cut, through the seclusion period to the pass-out rite. Although sikhebo is a social-cultural ceremony, the whole process ritual is full of literary stylistic devices that contribute to its acculturative dramatic appeal. The research design adopts an analytical design. The ritual was analysed as a creative entity in which there exists a creative and fluid relationship between the performer and the audience realised through the employment of various modes of expression. It also used purposive sampling to select performances from three initiates with their parents, three neighbours, three circumcisers and five other relatives who formed the cast of the cultural theatrical piece. The study engaged non-participant observation and four Focus Group Discussions as the main methods of data collection. The performances were video recorded. Secondary sources helped the study to formulate the background, theoretical framework, literature review, research design, data analysis and ethical considerations. The study concluded that literary stylistic devices help in the development of plot in sikhebo as well as express the community's customs, traditions, beliefs and ideals.
\end{abstract}

Copy Right, IJAR, 2019,. All rights reserved.

\section{Introduction:-}

Commenting on the literary stylistic devices in ritual drama, Turner (1977) observes that actors in rituals sometimes break the moral conventions of the mundane society. They behave in a manner precisely contrary to ordinary social expectations. This role inversion happens because they enact an event that belongs to the other world; they invert whatever is appropriate to the profane world. The scholar adds that the performers may sometimes act hostilities that are never expressed in normal circumstances while appearing to deny some moral codes of the society of which, on deeper analysis they in fact serve to strengthen them. Turner concurs with Wanyama (2005) who affirms that performers are at liberty to use obscenities that afford them innocent joy. In this

Corresponding Author:-Paul Wanyonyi Khaemba.

Address:-Maseno University, P. O. Box P.O. Box 3275-40100, Kisumu, Kenya. 
instance, singers employ poetic license and drop euphemism. These scholars reiterate the view by Aristotle (1895) that catharsis consists in the purgation of the excessive emotions of pity and fear. Aristotle adds that pity alone would be sentimentality and fear alone would make us cowards. However, pity and fear, sympathy and terror together constitute the tragic feeling, which is most delightful. The input of these scholars that dramatic elements are evident in ritual performance is vital to the present study. However, the works of these scholars are limited to poetic license and do not say much about literary stylistic devices such as repetition and symbolism that aid in acculturative dramatic realization of the ritual.

According to Kwakwa (1982), in a ritual setting, symbolism provides visible, audible and tangible evidence of the beliefs and values that cannot be readily perceived. He observes that totality of perspective based on the social and cultural values of the group is the essence of the African aesthetics. Kwakwa adds that the integrity of the art in the African ritual is protected because of the education, which prepares all members to become arbiters. Its proportion is guided by careful attention to scale and degree of intensity in music, dance, structure, time and space. La Fontaine (1994) also observes that the non-verbal aspects including the objects worn, carried by and constructed around the initiates serve a communicative purpose. Similarly, Wanyama (2005) concurs with La Fontaine that body art, costumes and props used in the performance of sikhebo are symbolic and functional. The view by Kwakwa, Wanyama and La Fontaine's that ritual performance involves aesthetics is important to the present study. Nonetheless, the scholars do not identify the specific dramatic elements evident in ritual performance. Additionally, their works are limited to symbolism and do not discuss other literary genres like oral poetry and self-praise that aid in dramatic realization. Therefore, the present study sought to analyze all the literary stylistic aspects evident in sikhebo and their contribution in the realization of the ritual's acculturative dramatic appeal. Commenting on Soyinka's use of proverbs in ritual performance, Gibbs and Lindfors (1993) affirm that proverbs are used widely in ritual drama because of their effectiveness in persuasion. They add that proverbs are capable of carrying the audience to the heart of drama. These authors often find it sufficient to articulate the beginning of a proverb and assume that their learned audience is able to complete the phrase and would know immediately how to apply this to the situation at hand. They affirm that ritual drama incorporates proverbs as useful metaphorical devices. Gibbs' and Lindfors' argument that proverbs aid in dramatic development in ritual performance forms the basis of the study. However, their study is limited to proverbs and excludes other literary genres such as songs and symbolism that serve dramatic purposes. Moreover, they do not discuss the role of proverbs in transmitting society's culture.

Rodney (1989) states that there is effective African traditional education through proverbs, songs and sayings, which is tangible, definite and intelligible in male circumcision. It is essentially an education for living with the main aim of preparing the youth for adult life. It is education intertwined with social life and meant to socialize the young into norms and beliefs of the wider society. Simiyu (1990) concurs with Rodney by observing that proverbs are used as a form of education that places emphasis on the learning of practical skills and the acquisition of knowledge, which is useful to the individual and the society as a whole in male circumcision. The education puts emphasis on social responsibility, job orientation, political participation and spiritual moral values. Simiyu adds that it is after a person is circumcised that he is allowed to join a new class of adults to take up new responsibilities. Though Rodney and Sifuna discuss acculturation in sikhebo, they do not discuss the dramatic elements evident in proverbs, songs and sayings a gap that the study addresses.

Wanyama and Egesa (2015) posit that song in the context of sikhebo adds to the development of the ritual's plot. Moreover, they note that songs are used to lengthen the performance by facilitating the movement of the actors from the initiates' parents' home to the relatives, neighbours and friends' homes. The actors equally use song as a channel of communication. Therefore, Babukusu reaches out to its intended audience through song. Additionally, the initiates are told through song their responsibilities and how they should carry themselves afterwards. Wanyama and Egesa also concur with Wanyama (2005) who observes that there is aesthetics in songs marked by the use of parables, satire and allusions that have educative and social control functions for the initiates and the community at large. According to Wanyama, Babukusu circumcision songs are meant to excite and inspire the performers. Wanyama adds that most aesthetic aspects in Babukusu circumcision music are embodied in its form, context and performance. The views by Wanyama and Egesa that songs help in the ritual's dramatic development are vital to the study. Nonetheless, their study is limited to song as a genre, omits other literary stylistic devices such as proverbs, and self-praise that this study addresses. 
Makila (1978) postulates that Babukusu clans are believed to have been originated by men, their special oaths and praises known as bibilao-noun from the verb khukhuwilaa, which members invoke in their regular introductions, are heavily lanced with material links. Makila adds that the image of the female is an instrumental trope of mobilizing cultural emotions around Babukusu. Makila avers that Babukusu identity is not just about mentioning one's clan or lineage, but also about celebrating history by heaping praises on past clan conquests and peculiarities. Makila affirms that a Bukusu man is supposed to begin mentioning his name and ancestries known as khukhwitacha. He will then move on and begins pronouncing platitudes about his paternal ancestry and bragging about the achievements associated with his lineage and clan heroes known as khukhwilaa. Makila's view that selfpraise involves dramatic actions formed the basis of this study. However, his study does not discuss the paralinguistic aspects like gesticulation, eye-balling, facial expression and intonation that contribute in the acculturative dramatic realization in sikhebo.

In analysing communicative aspects in the performance of rituals, Bell (1992) argues that two issues are involved and often collapsed in any consideration of ritual drama use of language. First, the ritual use of language and second, the comparison of ritual as a language with verbal or textual languages in the sense that its activities parallel the communication functions of the latter. She postulates that ritual words are deeds that accomplish things and that there is an assumed identity between the word and the deed. Bell implies that ritual representation is not just an alternative way of expressing something but the expression of things that cannot be expressed in any other way. Were (2013) concurs with Bell that songs sung during sikhebo are sung in a language that expresses the activities pertaining to the ritual. Bell and Were's assertion that language use in ritual is full of action geared to bring out elaborate meanings is important to the present study. Nevertheless, the scholars' limited their focus on language and do not explore other literary stylistic devices such as songs and symbolism that are dramatic. The study assessed all the literary stylistic devices in the performance of sikhebo that contribute to the ritual's acculturative dramatic appeal.

Freytag (1963) postulates that a narrative includes events that make up a story, particularly as they relate to one another in a pattern, in a sequence, the causes and effects, how the reader views the story; or simply by coincidence. Freytag adds that one is generally interested in how well this pattern of events accomplishes some artistic or emotional effect. His assertion that ritual performance follows a planned cycle is vital to the study, which analyzes sikhebo as a planned ritual from its preparation stage, ritual cut through to the seclusion period and ultimately pass-out rite. However, Freytag's study deals with narration and does not discuss other literary stylistic devices like songs, and symbolism that aid in the ritual's acculturative dramatic realization.

\section{Research Questions}

1. Why are songs used in the performance of sikhebo?

2. How is self-praise manifested in the performance of sikhebo?

3. What is the use of proverbs in sikhebo?

4. Why is symbolism used in the performance of sikhebo?

5. How is satire used in sikhebo?

6. Why is repetition used in the performance of sikhebo?

7. How is diction manifested in the performance of sikhebo?

8. Why are ululations and cries used during the performance of sikhebo?

9. What is the importance of onomatopoeia in performance of sikhebo?

\section{Statement of the Problem}

Literary stylistic devices are evident in ritual drama performed during birth, naming, initiation rites, hunting, marriage, spirit possession and death ceremonies. Literary stylistic devices evident in the above-mentioned rituals help in the development of drama as well as express the community's customs, traditions, beliefs and ideals. Despite the depiction of literary stylistic devices evident in the ritual performance that should be subjected to literary analysis, scholars who have carried empirical research on sikhebo do not assess the literary stylistic devices as acculturative dramatic narrative. The performance of sikhebo among Babukusu falls within the purview that was of particular concern to the study. As such, the study sought to discuss literary stylistic devices in sikhebo as an acculturative dramatic narrative. 


\section{Materials and Methods:-}

The study employed an analytical research design to analyze sikhebo as a creative entity in which there exists a creative and fluid relationship between the performers and the audience realized through the employment of various modes of expression. The study was conducted in Bungoma North Sub-County of Bungoma County. The SubCounty is divided into twelve administrative locations, namely: Mukuyuni, Mbakalo, Milima, Kabuyefwe, Naitiri, Kakamwe, Soysambu, Mitua, Tongaren, Ndalu, Kiminini and Kibisi.

The study employed purposive sampling to select performances from three initiates with their parents, three circumcisers, three neighbours and five other relatives who formed the cast of the cultural theatrical piece. Apart from the initiates, all the participants in the performance of sikhebo acted as the audience. Primary data was collected using non-participant observation, which involved studying the form, content and context of performance of sikhebo in order to get a clear picture of the ritual. During non-participant observation, the following was observed: the procedure, roles specification and participation of each performer, and the non-verbal aspects of the ritual namely, the costume, props, body adornments, body movements and gestures. The ritual observation was done with regard to the stages of sikhebo.

Secondary data was obtained from written materials, which include journal articles, online journals, seminar papers, books, articles, MA and PhD theses and dissertations from Universities across the world. Data collected from the field was analyzed analytically using textual analysis to show the contribution of literary stylistic devices in the realization of the ritual's acculturative dramatic appeal. Recorded information on videotapes was transcribed and translated to come with statements and conclusions. It was then analyzed qualitatively to identify themes that addressed the objectives of the research.

\section{Results and Discussion:-}

\section{Use of Songs in the Performance of Sikhebo}

In the performance of sikhebo, songs are used to mark different stages, to educate, to ridicule people who have bad behaviours, to recount history and current events and to provide moral guidance. During rehearsals, Kundu, Bunyasi and Wafukho (male escorts) sing the song entitled "Mulongo" as the teach Wanyama, Masafu and Werunga how to play jingles and dance to circumcision songs. It was observed that as Kundu sings the line that says, "Child of my mother be strong" and Bunyasi and Masafu reply by saying "Hahoo" male escorts stamp their feet on the ground as they carry clubs to scare the initiates. During this time, Bunyasi uses hand gesticulation to teach the initiates to play jingles and dance stylishly to the song. It was observed that Bunyasi slaps Masafu for not dancing to circumcision songs and playing jingles to the tune as instructed. During this time, Wanyama, Masafu and Werunga put on brave faces as they observe keenly what they are told by Bunyasi. According to information gathered from the field, the song is meant to announce to prospective initiates, parents, stakeholders and relatives that the session for sikhebo is approaching as well as look for appropriate costume to use during the time they set to invite visitors. As a result, all must prepare adequately by ensuring that there is enough food to feed visitors and animals for offering sacrifices. The song also encourages Wanyama, Werunga and Masafu to be strong during the circumcision period.

During the time that Wanyama, Werunga and Masafu set to invite relatives, friends and neighbours to attend the circumcision ceremony, the song that is sung by Bunyasi, Kundu, Wafukho, Nakhumicha and Nasipwondi (male and female escorts) is entitled "luwaya". It was observed from the field that as Kundu leads the crowd to sing the line that says "the wire that gave birth to the initiate", Bunyasi, Wafukho, Nakhumicha and Nasipwondi respond by saying "the wire". During this is the time, Wafukho and Bunyasi hold their penis as they direct where Nakhumicha and Nasipwondi are as they walk in a marching pace. Similarly, the female escorts dance provocatively as they lift their dresses as they face their counterparts indicating they are ready for sexual intercourse. As observed from the field, Wanyama, Masafu and Werunga put on brave faces as they dance stylishly to the tune of the song. Notably, this is the time that the initiates chests and backs are decorated with beads known as butundi that form letter X. The song "luwaya" is used metaphorically to refer to the initiates" penis that should be operated to prepare them for the future responsibility of indulging in sexual intercourse. Notably, Wafukho tells Wanyama, Masafu and Werunga that the essence of the penis is not for beauty but for siring children so that the tribe can expand. The above argument is replicative of what happened to Mango who was given a Sebei girl to marry after undergoing circumcision. During field study, men and women who engage in sexual intercourse are applauded for they teach the initiates how it should be done. 
While escorting Wanyama, Masafu and Werunga from Wakhisi's place (the maternal side), Kundu leads the crowd to sing the song entitled "Mayi wo Mwana' It was noted that as the soloist sings the line that says, "The child resembles a fox", the crowd responds by saying "Eh! Mother to the child come and see". Kundu puts on a brave face as Wafukho, Bunyasi, Nakhumicha and Nasipwondi finger point Wanyama, Masafu and Werunga who are smeared with yeast to show that they are different and they must be circumcised in order to be accepted in the family. Likewise, the escorts finger point the coloured he - goat as they walk in a matching pace behind the initiates to show the crowd how Wakhisi has honoured the initiates. During this time, Wanyama, Masafu and Werunga put on brave faces and focus their eyes in front to show that they are serious as the song informs them that time is running out for them to face the knife.

On the eve of the circumcision day, the song that is commonly sang is entitled "Babuya" It was observed that as Kundu (the soloist) sings the line that states "Ee! Rirr! Truly make tremors that will shake the earth" and the crowd respond by saying "Babuya is a bad clan eh! Singers dance in a circular manner while stamping their feet on the ground. This is the time that Bunyasi and Wafukho produce war cries as Nakhumicha and Nasipwondi ululate to express joy towards the performance of sikhebo. It was observed that as the crowd sing, Kundu, Wafukho and Bunyasi arrange themselves close to one another and even closer to the initiates. The performance is in such a way that no single performer breaks away from the circle. However, Bunyasi dashes forward and returns to the rest. Performers display emotions through the provocative dance that allow them to dance without shame or fear of reprimand, which is supported by the high tone ululations from women. During this time, Kundu and Wafukho carry big clubs known as bicholon'go and sticks known as chisimbo shoulder high as if they want to hit Wanyama, Masafu and Werunga whom they surround as they dance in a circular pattern. It was noted that initiates put on brave faces and maintain eye contact with Bunyasi who dances in front of them. The use of big clubs known as bicholon'go and sticks known as chisimbo in performance of sikhebo is meant to threaten the initiates to be serious and gain the courage to face the knife. Likewise, carrying clubs and sticks is a reflection of both excitement and security because Babukusu derives satisfaction and security from the fulfilment of the ritual.

Likewise, the song that is commonly sung on the eve on the circumcision day is entitled "Kongona"meaning to finish. It was observed from the field study that as Kundu sings the line that states "Ee! Finish everything in this home you finish it and the crowd respond by saying "finish it" the singers dance in a circular manner as they surround Wanyama, Masafu and Werunga as they walk in a matching pace as they demonstrate using hand gesticulation to show the initiates that they should finish by undergoing circumcision successful. Wafukho uses hand gesticulation to inform the initiates that they are dancing to circumcision songs and playing jingles for the last time, hence, they must display all dancing styles. On their part, Wanyama, Werunga and Masafu play jingles as they stylishly dance to the circumcision songs. Additionally, the initiates put on brave faces as they maintain eye contact with Kundu, Wafukho and Bunyasi.

After resting for three hours on the eve of the circumcision day, Werunga, Wanyama and Masafu wake up at five o'clock to dance to circumcision songs and play jingles. The song that is commonly sung is entitled "Amba Mutalya" meaning to uphold the tradition of Babukusu community. As observed from the field, the song is lead by Nyukuri, a male elder aged eighty-five years. It was observed that as Nyukuri sings the line that says, "We sing and sing again this Mutalya for painful circumcision ritual is coming" he jumps and dances in front of Wanyama, Masafu and Werunga as he observes their eyes to gauge the level of seriousness. On the other hand, Kundu, Masafu and Werunga (the male escorts) dance in a matching pace as they surround the initiates. During this time, the initiates put on brave faces as they play jingles, as they stand straight with their eyes that are red in colour fixed on Nyukuri. The song "Amba Mutalya" is sung in a sad mood because after a while, the initiates face the knife. The song further encourages Babukusu to perpetuate the old circumcision tradition handed to them by Mango and other ancestors.

It was observed from the field that while escorting Wanyama, Masafu and Werunga to the sacred river that does not dry known as esitosi to be smeared with grey ochre known as litosi, the song that is commonly sung is entitled "liloba". It was noted that as Kundu sings the line that says, "Oh! The soil ( $\mathrm{x} 4$ ) that finishes us, the soil and the crowd reply by saying, "Oh! The soil (x4) that finishes us, the soil", singers were seen dancing in a matching pace as Wafukho and Bunyasi (male escorts) carry up clubs and produce war cries as Nakhumicha and Nasipwondi (female escorts) ululate to express joy. This is the time that the initiates play jingles to the tune of the song and dance stylishly while putting on braves faces as they focus their eyes in front. According to the information gathered from the field, the song reminds the initiates that their fore fathers were circumcised after they were smeared with sacred 
mud. Similarly, before Mango went to attack the serpent, he smeared himself with mud to get rid of his body odour so that the serpent could not notice him. Normally, Babukusu believe that sacred rivers are trampled upon during the period of sikhebo. Therefore, smearing the initiates with sacred mud provides them with extra powers to face the knife.

Similarly, as Wanyama, Masafu and Werunga approach the sacred river, the song that is sung is entitled "Orao Bachonga" meaning put it there to be chopped. It was observed that as Kundu sings the line that says, let them chop authoritatively, the crowd respond by saying, "put it there so that it can be chopped". During this time, Kundu, Bunyasi and Wafukho produce war cries as Nakhumicha and Nasipwondi ululate to express joy of expecting men in the family. Notably, singers point fingers, clubs and sticks at the initiates' shorts to demonstrate that they must present their penis to be cut without fear as they walk in a matching pace. Wanyama, Masafu and Werunga on their part display high level of seriousness by putting on brave faces and focusing eyes at one point as they dance stylishly and play jingles.

Ordinarily, while escorting Wanyama, Murefu and Werunga to Wekesa's home from the sacred river, the song that is sung by Bunyasi, Wafukho, Nakhumicha and Naspwondi (male and female escorts) is entitled "sioyayo". It was noted that as Kundu sings the line that says "You! You! You! The uncircumcised one" authoritatively, the crowd respond by saying "Hoo.o!" authoritatively. During this time, male and female escorts dance behind the initiates in a matching pace until they approach Wekesa's home. Nonetheless, the female escorts do not take a leading role. This is the time that Bunyasi and Wafukho carry clubs, sticks and twigs to scare the initiates as they produce war cries. During this time, Nakhumicha and Nasipwondi ululate to express joy. According to information gathered from the field, sioyayo is the song that Mango's mother sang as his son was being led to the circumcision ground. Mango's old mother burst into tears and cried "Woceli! Wooei! My only son. Ahaa! Hooh! Mango did I not tell you that circumcision is painful. You have chosen it by yourself. There you are" Babukusu turned the mother of Mango's painful words into a song known as sioyayo, which is sung while escorting the initiates from the sacred river to the fathers' grounds.

As noted from the field, sioyayo is sung five times in the entire performance of sikhebo. The first time is during the sanctification of the circumcision knives known as khubita chikembe after the chief circumciser appeases the ancestors and the gods to protect and bless the circumcisers during the circumcision period. The second time is during the performance of khuchukhila which, involves the mixing of fermented fried flour with yeast on the third day to the ritual cut immediately after Wekesa's (Wanyama's father's) address to indicate that in a short while the initiates are going to face the knife. The third time is when Wakhisi who is the initiates' maternal uncle orders Kundu to sing the song authoritatively after appreciating Wanyama, Masafu and Werunga with a coloured he-goat. Moreover, sioyayo is sung on the eve of the circumcision day after Wekhomba who is the initiates' paternal uncle addresses the initiates and dresses pieces of the bull's stomach meat known as khasombo around the initiates' necks to show that in a short while, the initiates are going to face the knife. Lastly, sioyayo is sung while escorting the initiates from the sacred river to instill bravery as the ultimate moment draws near.

After a successful operation, the song that is commonly sung is entitled "Khwera Omurwa" meaning we have killed the enemy. As observed from the field, as Kundu sings the line that says, "We have killed Omurwa, my brother we have killed Omurwa, the crowd respond by saying "Aaa! We have killed Omurwa" During this time, singers walk in a matching pace as they surround Wanyama, Werunga and Masafu to celebrate their success that recapitulates Mango's original triumph when he killed the python. This is the time that Nasambu who is Wanyama's mother, Nangami who is Masafu's mother and Namachemo who is Werunga's mother join the crowd in ululations as Kundu, Bunyasi and Wafukho (male escorts) roar as they put down clubs and sticks to appreciate the initiates for their bravery. This time, Nasambu goes to the house, comes with ripe bananas on a traditional tray known as lutelu, and throws to the crowd to signify plenty of food in the family. According to information gathered from the field, the song stresses the fact that Babukusu have reason to celebrate for having killed one of their perennial enemies known as Omurwa singular for Barwa. Barwa represent the Sabaot a sub clan of the Kelenjin who are highland Nilotes. The Sabaot live on the slopes of Mount Elgon and often clash with Babukusu over livestock and land ownership. Therefore, the song is meant to celebrate success and achievement over a hard obstacle.

The song that is sung during the performance of sikhebo to provide the denouement of the ritual is entitled "Lelo Mungumbo empia". As observed from the field, as Wanyama, Masafu and Werunga sing the line that says, "Today I am in new clothes," They walk in a matching pace to express joy of obtaining a new status as they return home from 
the river. This is the time that the initiates put on new clothes to reassure their parents, relatives and the entire community that they are now mature people ready to defend the clan from any form of aggregation.

During the time of administering the final pieces of advice to Wanyama, Masafu and Werunga, Mang'oli who is a male elder stresses the need for the initiates to unite using a song entitled "Amanani Kali Elwanyi" translated as "ogres are outside there". It was observed from the field that as Man'goli sings the line that says, "The ogres of war are out there waiting for you," he sings authoritatively as he maintains eye contact with the initiates to underscore the fact that they must unite with other age-sets to defend the community's interests and territory.

\section{Self-Praise during the Performance of Sikhebo}

As observed from the field study, all circumcisers meet at Khisa's home who is the chief circumciser in the month of July of the circumcising year to perform a ritual to sanctify the circumcision knives known as khubita chikembe. During this time, Khisa praises himself as he invokes the ancestors authoritatively through hand gesticulation to give the circumcisers namely Wanyonyi, Wafula and Maloba the courage to discern the initiates who may exhibit fear. This is the time that the chief circumciser implores the gods and the ancestors to bless and protect the initiates to go through the rite successfully so that they can become productive members of the society. The act of Khisa speaking authoritatively invokes the ancestors and the gods to protect the circumcisers and the initiates during the entire circumcision period.

Likewise, during khuchukhila, that involves the mixing of fermented fried flour with yeast. Wekesa who is the father to Wanyama's father, Masafu and Werunga uses authoritative language and hand gesticulation to inform the initiates that it was their personal decision to undergo circumcision and they should not embarrass themselves, the family and the entire community by exhibiting signs of fear. This is the time that Wekesa praises himself of coming from brave people. During this time, Wanyama, Masafu and Werunga put on brave faces as they maintain eye contact with Wekesa in order to get what they are told. The act of Wekesa using authoritative language and hand gesticulation during self-praise instills fear in the initiates as a result gain the required courage to face the knife.

Similarly, before Wanyama, Masafu and Werunga visit Wakhisi, the maternal uncle, they are decorated with beads known as butundi and smeared with yeast. As observed from the field, decoration is done by the initiates' paternal aunt called Namaemba known for her generosity, kindness and productivity of male children. During this time, Namaemba puts on a brave face as she uses hand gesticulation during her self-praise to encourage the nephews to be focused and courageous. This is the time that Wanyama, Masafu and Werunga are told that they come from a brave community and any fear witnessed during the ritual cut is attributed to the initiates' maternal side. Therefore, Namaemba's self-praise ensures that the initiates remain focused and determined to face the knife. Moreover, Namaemba's self-praise invokes the paternal ancestral spirits to bless and protect the initiates during the circumcision period.

Normally, while advising Wanyama, Masafu and Werunga to be courageous, Wakhisi, the initiates' maternal uncle puts on a brave face and maintains eye contact with the initiates as he praises himself of coming from a brave community. This is the time that he tells the nephews authoritatively that any fear witnessed during the ritual cut is attributed to the paternal side. Before Wakhisi smears Wanyama, Masafu and Werunga with yeast to protect and bless them during the circumcision period, he slaps them to instill fear. During this time, the initiates put on brave faces as they maintain eye contact with the maternal uncle. Wakhisi's self-praise invokes the maternal ancestral spirits to bless and protect the initiates.

Similarly, on the eve of the circumcision day, Nyukuri, the male elder uses authoritative language and gesticulation to warn Wanyama, Masafu and Werunga not to fear the knife because they come from brave people. Moreover, the male elder takes a piece of a bull's meat, blood known as kamalasile, local brew known as busaa and a stick obtained from a special tree known as kumulaha and place them at the centre of the shrine for the ancestors to feed on. During this time, he invokes the ancestral spirits to protect and bless the initiates against all forms of malice during the circumcision period. During self-praise, Nyukuri mentions the year of circumcision to show seniority as a result encourage the initiates to be courageous during the cut in order to earn respect in the community.

As observed from the field study, Wekhomba who is Wanyama, Masafu and Werunga's paternal uncle praises himself before he dresses pieces of the bull's meat known as khasombo around the initiates' necks. During the time of self-praise, Wekhomba speaks authoritatively as he warns Wanyama, Masafu and Werunga not to embarrass the family during ritual cut by fearing the knife because they come from a brave clan. This is the time that Wekhomba 
maintains eye contact with the initiates as he gauges the level of seriousness. He further slaps the initiates to instill fear. Moreover, as he dresses the pieces of the bull's stomach meat around the initiate's necks, Wekhomba encourages Wanyama, Masafu and Werunga to be courageous. Wekhomba's self-praise invoke the paternal spirits to bless and protect the initiates during the circumcision period. On their part, the initiates maintain eye contact with Wekhomba as they put on brave faces to show that they attentive.

Notably, in the morning of the circumcision day, Wanjala who is Wanyama, Masafu and Werunga's male paternal cousin who is authoritative and has good record of accomplishment is appointed to smear the initiates with grey ochre known as litosi. It was observed from the field study that Wanjala uses authoritative language and maintains eye contact with Wanyama, Masafu and Werunga to tell them to be focused and determined to face the knife because they come from a brave clan. Moreover, the paternal male cousin tells the initiates categorically that any fear witnessed is attributed to maternal side. On their part, the initiates put on brave faces and maintain eye contact with Wanjala an indication that they are focused. According to information gathered from the field, Wanjala selfpraise invokes the initiates' paternal ancestral spirits to protect and bless them.

One month after circumcision when Wanyama, Werunga and Masafu heal, Khisa the person who circumcised them come to perform a ritual known as khubita that involves the circumciser giving the initiates pieces of advice on how to behave as mature members of the family. It was observed that as Khisa chews fried dough called kamakhalange and spits on the heads of Wanyama, Werunga and Masafu, he repeatedly strokes their heads with the circumcising knife that operated them known as lukembe. This is the time that Khisa uses self-praise authoritatively as he maintains eye contact with the initiates to advise them to work hard so that they can provide for their families by use of the machete, axe and hoe. Similarly, initiates are told to protect the families from enemies and rear animals and birds. Additionally, Wanyama, Werunga and Masafu are told to show respect to all the people both young and old. While shaking the head, Khisa warns the initiates against drunkenness that can make them not to excel in life. During this time, Wanyama, Werunga and Masafu maintain eye contact as well as put on brave faces to show that they are attentive.

Normally, during khukambila, which involves giving Wanyama, Masafu and Werunga final pieces of advice, Man'goli the male elder maintains eye contact with the initiates and uses authoritative language to praise himself of coming from a clan of good morals. As observed from the field, this is the time that the initiates are warned authoritatively to keep safe distance from their mothers and other female members of the society as he shakes the head. Moreover, the initiates are taught sexual issues since circumcision prepares one for marriage. More so, Wanyama, Werunga and Masafu are taught Babukusu communal values such as bravery because their role is to defend the community. During his self-praise, Man'goli mentions the year of circumcision to show seniority. As observed from the field study, the initiates put on brave faces as they maintain eye contact with Man'goli to show that they are attentive.

\section{Use of Proverbs in Sikhebo}

During the early stages of the performance of sikhebo, as Wekesa gives Wanyama a go ahead to undergo circumcision he uses a proverb that states that emboko yaambukhila en'gana ya ambukhilamo translated as where the mother buffalo crosses the river is the same spot that the calf crosses. It was observed that as Wekesa says the proverb to the son, he maintains eye conduct and speaks authoritatively because it is the initiate's decision to undergo circumcision. During this time, Wekesa finger points Wanyama and uses slap gesticulation to instill fear. On his part, Wanyama maintains eye contact and puts on a brave face to show that he is focused. In the context of sikhebo, the proverb that Wekesa uses means that the cultural practices that were conducted by Babukusu ancestors since the time of Mango are the same ones that are practiced up to date. Therefore, stopping the community from practicing sikhebo in its traditional manner is like trying to stop them from producing young men who should propagate the lineage of the clan.

Similarly, Wekesa who is Wanyama's father uses a proverb that states that bubasi bulondaga silibwa translated as iron mongering is hereditary trade as he instructs Nasambu his wife to give Wanyama a hen to take to Wakhungu in exchange of two jingles known as chinyimba and two metal rings known as birere. It was observed that during this time, Wekesa uses authoritative language as he finger points the hen. Wanyama on his part puts on a brave face as he maintains eye contact with the father. According to information gathered from the field, iron mongering is handed down from father to son within a clan, and cannot be acquired. The art of blacksmithing deals with spirits known as kimisambwa that have powers to make jingles produce sharp sound. 
Likewise, during sanctifying of circumcision knives known as khubita chikembe in the month of July of the circumcising year, Khisa the chief circumciser uses a proverb that states that bukhebi bulondaga ekholo translated as the circumcision doctor's trade is a family trait. This is the time that Khisa uses authoritative language to appease the gods and the ancestors to give circumcisers the courage, be swift and have the ability to discern the initiates who may exhibit fear. As observed from the field, circumcisers namely Wanyonyi, Wafula and Maloba observe keenly. According to information gathered from the field, there are three clans among Babukusu possessed with circumcision spirits, namely Bamasike, Bakhone and Babasaba. Therefore, women and men from the above three mentioned clans faint or shiver whenever a sacred song known as sioyayo is sung. However, only men are allowed to practice the art of circumcising. On the contrary, women who are possessed with circumcision spirits are treated by drinking traditional herbs known as kamanyasi and hitting their heads with circumcision knives as they get hold of the circumcising knives known as chikembe that automatically stops fainting and shivering.

Notably, while giving Wanyama, Masafu and Werunga the final pieces of advice on community values and ideals Man'goli the male elder uses a proverb that states enywinywi seyokesha mawe khupurukha ta, translated, as a pullet cannot teach a hen how to fly. During this time, Man'goli speaks authoritatively as he maintains eye contact with the initiates to underscore the role played by performers in teaching Wanyama, Masafu and Werunga community values and ideals. As noted from the field study, performers who execute rituals in sikhebo must be knowledgeable and have desirable character traits. Kundu, Bunyasi and Wafukho who are men escorts must have undergone the ritual and are informed as far as the details of sikhebo are concerned. Moreover, Namaemba who is the initiates' paternal aunt who is chosen to shave and decorate Wanyama, Masafu and Werunga is a woman of good conduct, kind and able to produce many children, especially boys. Besides, Wekhomba the initiates' paternal uncle and Wanjala the initiates' paternal male cousin selected to perform rituals of dressing a bull's stomach pieces known as khasombo around the initiates' necks and smearing the initiates with grey ochre known as khulonga respectively, are knowledgeable about the rituals they perform. Equally, Khisa the circumciser is a man of honour in the community, trusted of his surgical skills. Therefore, during the performance of sikhebo, performers have total authority and it is unethical for the initiates to ask questions as to why certain things are being done the way they are done. This caution is taken to make sure that no damage is done at any stage of performance.

As observed from the field, on the eve of the circumcision day, Nyukuri who is a male elder versed with Babukusu culture, circumcised and has a good record of accomplishment of accomplishment is selected to appease the gods and the ancestors. During this time, Nyukuri uses a proverb that states that enju eyo musumba sewombakhamo namwima ta translated as you cannot build a sacrificial hut in a bachelor's house. This is the time that Nyukuri puts on a brave face and speaks authoritatively to invoke the paternal spirits to protect and bless the initiates. Equally, he mentions the year he was circumcised to show seniority to encourage the initiates to face the knife with courage. On their side Wanyama, Masafu and Werunga observe keenly as they put on brave faces to show that they are focused. This proverb gives Wanyama, Masafu and Werunga the courage to face the knife in order to enjoy privileges like marrying and inheriting land.

After receiving the final pieces of advice, Wanyama, Masafu and Werunga are allowed to eat and drink the local brew known as busaa with Man'goli and Nyukuri. It was observed that Man'goli uses a proverb that states, kamalwa kaakhinia emboe,translated as beer can shake a tethered animal into dancing. This is the time, Nyukuri uses authoritative language as he shakes his head to warn Wanyama, Werunga and Masafu that alcohol can be harmful and stimulate a person to reveal the most concealed secrets to enemies. On their part, the initiates maintain eye contact with Man'goli and put on brave faces to show attentiveness.

Performance of sikhebo takes place in the month of August when schools are closed. Therefore, there are many people to participate in the ritual performance. As a way of preparing adequately for the visitors by ensuring that there is enough food and local brew known as busaa to make the visitors happy and bless Wanyama, Masafu and Werunga, Nasambu who is Wanyama's mother uses a proverb that states that omulange ali lulie, translated as an invitee is full of greed. While assuring Namaemba the initiates' paternal aunt that she has enough food and local brew known as busaa to make visitors happy, Nasambu finger points the two sacks of maize that are placed in her sitting room as she nods the head. On the other hand, Namaemba smiles as she nods the head to show that everything is in place. As such, the proverb reminds the community to prepare adequately by ensuring that there is enough food, local brew known as busaa and animals to offer sacrifices to the gods and the ancestors.

After a successful circumcision, Wekesa, who is Wanyama's father, appreciates his age-sets Walubengo and Masibo with local brew known as busaa and the bull's hind leg. During this time, Wekesa uses a proverb that states enyama 
bubolo wima busa owasio, translated as meat decomposes, why deny a friend a share? During this time, Wekesa puts on a happy face to appreciate his age-sets for their moral support as he uses hand gesticulation to show them the bull's hind leg and the local brew to share. As observed from the field study, Walubengo and Masibo appreciate Wekesa with a smile. The proverb highlights generosity of Babukusu people at ceremonies, which involve sharing of meat. More so, the proverb insists on the virtue of trustworthiness and honesty among age-sets.

Normally, while advising Wanyama, Masafu and Werunga how to carry themselves during the seclusion period, Khisa the circumciser uses a proverb that states enjala ekhukhola omwana, translated as hunger or starvation can make one seem like a child. As Khisa advices the initiates, he uses authoritative language and hand gesticulation to tell Wanyama, Masafu and Werunga to make friendship with farming tools like the hoe, an axe and the machete so that they can have plenty of food in their homes. It was observed that as Khisa displays the above-mentioned tools, he nods the head to show that the initiates should make friendship with the tools. Subsequently, Khisa shakes the head to discourage the initiates to be lazy because a hungry person who has no source of food can beg like a child. On their part, Wanyama, Masafu and Werunga maintain eye contact with Khisa as they put on brave faces an indication that they are focused to face the knife.

As observed from the field, initiates are treated using traditional herb known as enguu during the seclusion period. After applying the herb on Wanyama, Masafu and Werunga penis, Lukibisi who is Wanyama's elder brother uses a proverb that says enguu serora oli nakhuakhilekho ta, translated, as you cannot dream of circumcision medicine called enguu. This is the time that Lukibisi maintains eye contact with the initiates and speaks authoritatively in order to earn the initiate's respect. On their part Wanyama, Masafu and Werunga stands up as they hold their heads to show intense pain they are in because of the herb. According to information gathered from the field, enguu is usually bitter and is used to heal the initiates' wounds quickly as well as inculcate virtues of courage and tolerance in the initiates.

Khukambila is the time when Wanyama, Masafu and Werunga are given final pieces of advice on community's values and ideals. During this time, Man'goli, a male elder uses a proverb that says, kumwikule kukwoo ne kumwikale kwabeene, translated as an open door is yours and the closed one is somebody else's. This is the time that Man'goli uses authoritative language and hand gesticulation to tell the initiates that their sexual organs are not for beauty but for a specific purpose of siring children. Man'goli nods the head and maintains eye contact with Wanyama, Werunga and Masafu as he reminds them that they exist because their parents had sex and circumcision is pegged on marriage. This is the time that Man'goli nods the head and maintains eye contact with the initiates to show approval. On the contrary, he shakes the head as he warns Wanyama, Masafu and Werunga against disrespecting other people's wives and fearing girls.

Likewise, it is during the giving of the final pieces of advice that Wanyama, Masafu and Werunga are told by Man'goli the history of the circumcision age-sets among Babukusu. As observed from the field study, Man'goli uses a proverb that states bibingilo sebinyolanaga tawe translated as circumcision groups cannot meet. During this time, the male elder uses authoritative language as he mentions the year of circumcision to show seniority. Man'goli goes ahead to inform the initiates that there are eight circumcision age-sets namely Bakolongolo, Bakikwameti, Bakananachi, Bakinyikeu, Banyange, Bamaina, Bachuma and Basawa. The age-sets are spaced in a way that each lasts for ten years apart from Bachuma that lasted for fourteen years. The circumcision age-set of the year 2018 is named Bakikwameti number three of handshake between President Uhuru Kenyatta and Mr Raila Odiga. Equally, while stressing the need for the initiates to unite, Man'goli uses a proverb that says, litere lilala selira enda tawe, translated, as one nail cannot kill a louse. This is the time that Man'goli speaks authoritatively as he maintains eye contact with the initiates as he tells them to unite and protect the community's territory. As observed from the field, this is the time that Wanyama, Werunga and Masafu are given spears by Wekesa to throw accurately enough so as they piece and stick in the ground as they shout, "we have killed the enemies" to show their protective role in the community.

\section{Symbolism in Sikhebo}

In performance of sikhebo, the use of props, dance, body art, costumes and ornaments is symbolic. For instance, on the third to circumcision day, Wekesa (Wanyama's father) conducts a ritual known as khuchukhila that involves the preparation of the local brew known as busaa. As observed from the field, Wekesa takes a small pot known as esachi and places outside his house in a depression. The pot is decorated with star grass known as lukhafwa that symbolizes prosperity, perpetuation and tenacity. Wekesa then gives Wanyama, Masafu and Werunga another small pot that 
they carry on their shoulders in turns as they go and come from the river escorted by Lukibisi their elder brother to symbolize that they are doing female cores for the last time. It is worth noting that while going and coming from the river, Wanyama, Werunga and Masafu are not supposed to look back, sideways or talk to anyone to symbolize that they are focused. In addition, while coming from the river, the initiates are expected to use a different route from the one that they used while going to show that they have stopped behaving like children. According to information gathered from the field, there is symbolism in the water that the initiates take directly from the river that flows. The water that flows is preferred because it is running meaning, it helps to usher the initiates into manhood as well as ensure that life flows continuously unlike the static water kept in the house.

Moreover, immediately Wanyama, Masafu and Werunga arrive in Wekesa's home from the river, they pour water in the small pot in the pot placed outside that contain fried dough known as kamakhalange mixed with yeast in turns. According to information gathered from the field, millet is extensively used during the preparation of the local brew known as busaa because of its high multiplication rate during production. In the entire performance of sikhebo, busaa is used to bless Wanyama, Masafu and Werunga to be productive in future. Likewise, when yeast is put in the dough being brewed, it catalyses the maturation process from tasteless water in the first day to a bitter concentration brew on the third day when Wanyama, Masafu and Werunga go to invite Wakhisi the maternal uncle. Therefore, the process of preparing busaa is symbolic because as the brew gains its maturity, Wanyama, Masafu and Werunga turn into tough individuals by the time they go to Wakhisi's place on the third day. They are mature as the brew that they brewed on the first day, ready to face the knife.

Before Wanyama, Masafu and Werunga start inviting relatives, friends and neighbours, Namaemba the initiates' paternal aunt known for her good behaviour, is kind and has ability to give birth to many children especially males is called to shave off the initiates' boyhood. She further decorates Wanyama, Werunga and Masafu with beads known as butundi, which crisscross on the initiates' chests and backs to form shape of letter X. It was observed that as Namaemba decorates and shaves the initiates, she puts on a brave face and uses authoritative language to advice the initiates to be courageous during the cut, get married and give birth to children since manhood is assessed in terms of the above features. The act of the paternal aunt decorating the initiates makes them realize that they are unique as a result learn that they are the centre of attention thus; help them to gain the courage to face the knife. Likewise, before Wanyama, Masafu and Werunga go to visit Wakhisi (the paternal uncle); they are decorated with yeast on the heads, hands, chests and legs by Namaemba the initiates' paternal aunt. This makes them look unique as a result gain the required confidence to face the knife. In addition, before the initiates leave to Wakhisi's place, they are decorated with yeast to bless and protect them from any form of malice. Normally, before Wanyama, Masafu and Werunga start inviting relatives, friends and neighbours, they chose the costume to put on for the four days. As observed from the field, Wanyama, Masafu and Werunga put on pairs of shorts as they leave the upper part for decoration. The costume the initiates put on makes them look unique as a result, they are spotted easily by passersby to be reprimanded and encouraged because the costume is not put on for fun. As a result, the initiates gain the courage to face the knife.

On the third day to the circumcision day, Wanyama, Werunga and Masafu visit Wakhisi their maternal uncle for gifts and blessings. As observed from the field, Wakhisi who benefited from the bride prize of Nasambu, Wanyama's mother is chosen to conduct a ritual known as likhoni that involves appreciating the nephews with a bull or a he-goat. As witnessed from the field, Wakhisi appreciates Wanyama, Masafu and Werunga by giving them a coloured he-goat. However, if the maternal uncle is not in position to appreciate the nephew, tradition demands that he ties a special grass known as lukhafwa around the initiate's necks as a sign of blessing him and a promise that he will give him a bull in future. Moreover, after appreciating Wanyama, Werunga and Masafu, Wakhisi smears them with yeast on their bodies to protect them from malicious people who may bewitch them to fear the knife because any fear witnessed during the ritual cut is attributed to the maternal side. According to information gathered from the field, likhoni as a ritual teaches Wanyama, Werunga and Masafu that they belong to both their fathers and mothers' clans. This is especially important because when misfortune befalls them at their paternal sides, they take refuge in land of their mothers.

On the eve of the circumcision day, male escorts who are Bunyasi, Kundu and Wafukho carry twigs and clubs shoulder high as if they want to hit Wanyama, Masafu and Werunga as they dance in a circular pattern. The carrying of clubs and twigs creates fear in the initiates, which help them realize that the performance of sikhebo is a serious affair. Likewise, the act of singers dancing in a circular manner signifies that all members of the family are important and no one can live without the help of the others. Similarly, during the ritual cut, male escorts carry clubs 
and twigs shoulder high to scare the initiates from fearing the knife. However, after a successful ritual cut, Wafukho, Bunyasi and Kundu put down the twigs and clubs to appreciate Wanyama, Murefu and Werunga's bravery.

On the morning of the circumcision day, Wanyama, Masafu and Werunga are taken to the nearest river known as esitosi where they are smeared with grey ochre known as litosi by Wanjala who is the initiates' paternal cousin. During this time, Wanjala uses authoritative language to praise himself to instill fear before instructing the initiates to immerse in cold water to make blood numb. It was observed that after smearing Wanyama, Werunga and Masafu with grey ochre, Wanjala plucks a special grass known as lusinyande and sticks on Wanyama, Masafu and Werunga's heads in a process called lwanantu. According to information gathered from the field, the special grass symbolizes a number of things. First, it underscores the respect that the community has on the performance of sikhebo. Secondly, the special grass signifies that the initiates are communicating to the gods and the ancestors to give them extra powers to face the knife. Thirdly, the grass and the mud signify the materials that the initiates would use to construct their houses. Besides, the grey ochre smeared on the Wanyama, Masafu and Werunga's heads symbolizes the head of the serpent that Mango killed while the special grass symbolizes the serpent's tongue that came out of its mouth. Notably, it resembles a poisonous bird known as ututu renowned for having poisonous features that indicates the pain that Babukusu community endure while undergoing the cut. The circular chopping action that is employed in removing the initiates' foreskins during the actual cut by the circumciser is compared to the act that Mango used to kill the serpent using a sharp fierce knife. Similarly, the stinging fire that was produced by the serpent signifies the circumciser's knife that is known to inflict pain on the initiates.

During the sanctification of the circumcision knives known as khubita chikembe, circumcisers namely Khisa, Wanyonyi, Wafula and Maloba hold the circumcising knives with blades facing up as they sing sioyayo. Likewise, after circumcising Wanyama, Masafu and Werunga, Khisa hold the circumcision knife with blade facing up as he run to go and circumcise in another place in the company of Wafula. According to information gathered from the field, the act of circumcisers holding circumcising knives with blades facing up during the circumcision period signifies the ever erection of the Mubukusu man.

After smearing Wanyama, Masafu and Werunga with grey ochre known as litosi by their paternal male cousin Wanjala, they are escorted to Wekesa's home using a different route as Masafu, Wafukho and Lukibisi carry twigs and sticks high as they sing sioyayo. According to information gathered from the field, the act of escorting Wanyama, Masafu and Werunga to Wekesa's home using a different route from the one they used while going to the sacred river indicate that they should behave maturely. Likewise, immediately, Wanyama, Werunga and Masafu reach home, they are welcomed by their fathers namely Wekesa, Ndalila and Matere respectively who direct them to stand on the circumcision spots known as chitian'gi as they face East. According to information gathered from the field, facing East signifies that new members have entered the adult community in the same fashion as the rise of the sun signifies a new day. Additionally, the blood that spills on Wekesa's ground signifies the confirmation to the ancestors that Wanyama, Masafu and Werunga are part of the society the ancestors left.

As observed from the field, during the ritual cut, Wanyama's mother called Nasambu, Masafu's mother called Nangami, Werunga's mother called Namachemo and the initiates' paternal aunt called Namaemba sit on the floor of Nasambu's house in the company of other women with their legs horizontal to the floor waiting for a signal from Khisa the circumciser. According to information gathered from the field, the act of the initiates' mother, the paternal aunt and other women-seating horizontal on the floor symbolizes the position that Nasabu, Nangami and Namachemo exhibited on the day they gave birth to Wanyama, Masafu and Werunga. After a successful ritual cut, the songs that are sung are majorly war songs. As observed from the field, the song that is commonly sang is entitled "Khwera Omurwa" meaning we have killed the enemy that is meant to celebrate the success and achievement over a hard obstacle. During this time, women join in singing of war songs with choruses of ululations and dances of triumph around Wanyama, Masafu and Werunga. As noted from the field, the women's presence and the dance patterns symbolize that they (women) are ready for sexual advancements from the new men.

Moreover, after Wanyama, Masafu and Werunga undergo circumcision successfully, Nanyama who is Wanyama's sister, Nasimiyu who is Masafu's sister and Nangila who is Werunga's sister are called upon to hold the initiates waists. After the crowd is through with singing, the initiates' sisters give the initiates a place to sit and cover them with blankets for they are mature people who should not espouse their nakedness anyhow. According to information gathered from the field, the act of the initiates' sisters holding the initiates' waists after a successful operation signifies the dividends that Mango received after accepting to be circumcised: The Sebei girl as a wife. As such, 
Wanyama, Masafu and Werunga are entitled to Nanyama, Nasimiyu and Nangila's bride prizes when they get married.

Likewise, after receiving presents from parents, relatives, neighbours and friends, Wekesa, Matere and Ndalila direct their sons Wanyama, Masafu and Werunga respectively to the hut where they stay during the seclusion period known as mwikombe. According to information gathered from the field, the act of Wekesa, Matere and Ndalila directing their sons around the hut in reverse and finally entering symbolizes the way the serpent entered the cave after realizing that there was no danger: it entered backwards and finally placed the head on the log that was placed by the entrance by Mango. Secondly, the act signifies that Wanyama, Masafu and Werunga are no longer children, but mature people ready to defend the community. Furthermore, mwikombe symbolizes the place where people go when they die. Therefore, after circumcision, the new circumcised initiates are ritually dead and must be confined to a place where they cannot interact with the rest of the community freely until they undergo the stipulated rituals. In the month of December after Wanyama, Masafu and Werunga heal, Wekesa, Ndalila and Matere set the date when their sons should graduate. As observed from the field, on the eve of the pass-out day, Wekesa instructs Wanyama, Murefu and Werunga to take the bedding they were sleeping on during the seclusion period outside his house. Wekesa further instructs the initiates to get hold of dry banana leaves and twigs. It was observed that as Wekesa lights the matchbox and lights the bedding, Wanyama, Murefu and Werunga are instructed to light the dry banana leaves and twigs using the fire that burns the bedding. Moreover, the initiates are told by Wekesa to run towards the banana plantation while calling out loudly as they abuse the circumciser who is Khisa. The act of burning the initiates' bedding signifies that they are preparing to start a new life. Likewise, running with burning fire from Wekesa's compound to the banana plantation signify blessings that the initiates get from parents. In addition, the act of the initiates abusing the circumciser signifies that men are circumcised once.

On the eve of the pass-out, Wanyama, Werunga and Murefu spend the night outside in a temporal structure known as sisali. It was observed that the fire that the initiates light should not go off until morning. In addition, the initiates should not doze; it was observed that when Murefu tried to doze, he was hit by hot bananas to make him awake. Additionally, during this time, Wanyama, Murefu and Werunga are told legendry stories by Bunyasi, Wafukho and Kundu. According to information gathered from the field, the fire that burns continuously at night on the eve of the pass-out day reminds the initiates of their contribution to the continuity of life in the community. Hence, the fire is seen as sacred. Its sacredness symbolizes the sexual life of the initiates now that they have undergone circumcision; they have the licence to take part in sexual matters that ensure the continuation of the community's lineage. The act of Wanyama, Werunga and Murefu spending out in the wilderness signifies that they should protect the community against any form of aggression. Additionally, the act of Kundu, Bunyasi, Wafukho and Lukibisi narrating legendry stories to the initiates is to cultivate bravery in them so that they can protect the community against aggression.

It was observed that when Wanyama, Murefu and Werunga visit the maternal uncle who is Wakhisi, they are appreciated by giving them a healthy coloured he-goat. Similarly, on the eve of the circumcision day, Wekesa provides a healthy coloured bull to be slaughtered. It was noted that after a successful ritual cut, Wekesa, Matere and Ndalila appreciate their sons by giving them a healthy bull for their bravery. According to information collected from the field, Babukusu believe that health animals ensure that the life of the initiates is blessed if they are able to marry and sire many male children to sustain the family's lineage. However, deformed animals are associated with bad luck and when used cause harm to the initiates evidenced by their inability to marry, fear for women and impotence. The undesired deformities in animals include blindness, castration and lameness. Moreover, the animals that are slaughtered during the performance of sikhebo must bear bright colours. It is believed that bright colours signify bright future in the initiate's lives while dark colours signify dom. Furthermore, sikhebo is meant to transform the initiates from boyhood to manhood as well as bless them. Subsequently, animals used for sacrifice as well as the skin to be won while performing the rituals have to come from a bull or a he-goat. This skin is believed to instill extra powers to the initiates to enable them be courageous and firm during the cut. On the other hand, performers do not wear rams skins, for it is believed that rams are commonly used to offer sacrifices that block bad spirits from disturbing people.

\section{Satire as used in Sikhebo}

Songs sung during the performance of sikhebo criticize human weakness and faults through laughter with the ultimate noble aim of bringing about reform or keeping other human beings from falling into similar vices. The use of satire in circumcision songs encourages people to embrace positive values in an enjoyable manner. On the eve of the circumcision day, Bunyasi, Wafukho, Lukibisi, Nakhumicha and Nasipwondi (male and female escorts) sing the song entitled "Babuya". It was observed from the field study that as Kundu the soloist sings the lines that say, "Ee 
Babuya is a bad clan I reveal they cooked chameleons for people" and "Ee! Men of nowadays have sworn never to marry girls from Babuya clan". Kundu ridicules Babuya, a sub-clan among Babukusu that practices witchcraft. The song therefore, warns other Babukusu clans to avoid marrying or getting married to Babuya clan. Therefore, people who listen to the song embrace positive values in an enjoyable manner to avoid ridicule. Likewise, as Kundu sings the song entitled "Wambumuli" the line that says, "People will kill you because of people's wives and school children" he ridicules Wambumuli who is sexually immoral for he is fond of taking other people's wives and schoolchildren. Therefore, the song cautions Wambumuli and others who are sexual immoral that they will be killed because of being sexual immoral. The song therefore, wants Babukusu to be faithful in marriage.

\section{Repetition in Sikhebo}

Circumcision songs use repetition to make performance musical as well as create emphasis. During performance, the names of Wanyama, Murefu and Wekesa are repeated most of the time because they are the centre of attention. The act of mentioning the initiates' names repeatedly create confidence in them after realizing that they are the centre of attention, that give them the courage to face the knife. Besides, it is in performance of songs that singers emphasize that sikhebo is part of Babukusu tradition and that Wanyama, Murefu and Werunga must fulfill the tribe's old cherished tradition. Additionally, in historical songs like sioyayo and Amba Mutalya, the name of Mango is repeated in order for the initiates to ape his heroic characters of being courageous and brave. In addition, repetition is used to sustain the duration of the song and its memorization, since there are no alterations made in the performance. As such, this helps to maintain the originality of the song while giving the audience a chance to participate actively by engaging in the chorus.

\section{Diction in Sikhebo}

As a medium of communication, Lubukusu language is evident in the songs, proverbs and self-praise. These elements aid in plot development through actions that transmit cultural values and ideals to its people. The mood of the space and the conventions of performance of Babukusu circumcision songs allow for the use of obscenities. It was observed from the field that during performance, some words that are often viewed as taboo are uttered with ease. For instance, while singing the song entitled "Luwaya" Bunyasi and Wafukho say that they want to eat women or beat women water meaning that they are ready for sexual intercourse. Similarly, while uttering the above words, male escorts hold their penis in the direction where female escorts who are Nakhumicha and Nasipwondi are as a sign that they are ready for sex. On the other hand, female escorts reply that they are ready to receive water meaning that they are ready for sexual intercourse. During this time, women singers sing and dance provocatively while lifting their skirts towards their men counterparts to expose their thighs indicating that they are ready for sexual intercourse.

\section{Use of Ululations and Cries in Sikhebo}

Ululations and war cries are intensively used in performance of sikhebo. The two are inflexible features of style that mark excitement. As observed from the field, ululating is a preserve of women while men make war cries. The war cries produced by Kundu, Bunyasi and Wafukho (male escorts) during the preparation stage are meant to inform Babukusu that they are happy with the coming of the circumcision season; hence, need to prepare adequately. Secondly, war cries display Babukusu's love for the performance of sikhebo, since the community appreciates and cherishes the culture, which is passed from one generation to another. Similarly, when Wanyama, Masafu and Werunga visit Namaemba their paternal aunt, she appreciates by joining the crowd in singing, dancing and ululating an indication that she will attend the circumcision ceremony.

Moreover, when Wanyama, Masafu and Wekesa start inviting visitors and friends to witness the circumcision rite, Nasambu who is Wanyama's mother ululates in the morning before the initiates leave and in the evening when they return. The act of Nasambu ululating in the morning and in the evening signifies blessings that sons receive from parents to prosper in life. Additionally, Nasambu express the joy of getting men in the home who are the source of protection. Besides, the constant ululations encourage the initiates to remain focused after realizing that they are the centre of attention. More so, during the performance of khuchukhila, which involves the preparation of local brew known as busaa, Nasambu ululate after singing sioyayo to show that in a short while the initiates are going to face the knife.

Equally, when Wanyama, Masafu and Werunga visit the maternal uncle known as Wakhisi for blessings and gifts, Nafula who is Wakhisi's wife welcomes them with ululations. Moreover, when Wakhisi appreciates the initiates 
with a coloured he-goat, Nafula ululates immediately after sioyayo is sung to show excitement having been visited by nephews who is greatly honoured. The ululations produced by Nafula are meant to help Wanyama, Masafu and Werunga to remain focused and courageous. Moreover, while escorting the initiates to Wekesa's home from Wakhisi's place, Kundu, Wafukho and Bunyasi engage in war cries to appreciate Wakhisi for honouring the nephews. Similarly, immediately Wanyama, Werunga and Murefu arrive home, Nasambu who is Wanyama's mother, Nangami who is Masafu's mother and Namachemo who is Werunga's mother join the singers in ululations and dances to appreciate Wakhisi for honouring their sons.

Throughout the night of the circumcision day, Wanyama, Masafu and Werunga are chided through songs that are meant to encourage them to stay focused. Across the whole night, Nakhumicha and Nasipwondi ululate as Bunyasi, Kundu and Wafukho produce war cries while singing and dancing. The ululations and the cries also portray the liking attitude that Babukusu have for sikhebo. Besides, ululations and cries enhance the celebration mood because circumcision is the only platform that transforms boys into men. Further, at the sacred river, Kundu, Bunyasi and Wafukho engage in interludes of cries meant to scare women, men circumcised in hospital and uncircumcised boys away the sacred place where smearing takes place. Moreover, the war cries are meant to scare women and uncircumcised boys from taking a lead role while escorting Wanyama, Masafu and Werunga to Wekesa's home. Normally, after a successful operation, Nasabu, Nangami and Namachemo (the initiates' mothers) take a lead role in singing war songs and ululating around Wanyama, Werunga and Masafu to appreciate them for their bravery.

\section{Use of Onomatopoeia in Sikhebo}

While singing the song entitled "Babuya", Kundu the male soloist sings authoritatively the lines that say, "Ee! Rirr! Truly make tremors that will shake the earth" and "Sirr! You shake the earth and cause tremors," It was observed that as Kundu sings the two lines, he stresses the sounds Rirr! and Sirr! This is the time that he stamps his feet on the ground to imitate the sound of earthquake that causes the earth to shake and tremor. Likewise, as Bunyasi and Wafukho respond by saying, Ee! Babuya is a bad clan eh! They stamp their feet on the ground to produce the sound of the earthquake to show that the performance of sikhebo is a serious matter. Therefore, the use of onomatopoeic sounds Rirr! and Sirr! Give a clear picture of earthquake as described in the song.

\section{Conclusion and Recommendations:-}

The study affirmed that literary stylistic devices in the performance of sikhebo contribute to the realization of acculturative dramatic appeal. Literary stylistic devices develop plot in performance of sikhebo as well as express the community's customs, traditions, beliefs and ideals. It is recommended that a study be carried out to analyze dramatic elements in sikhebo as acculturative narrative.

\section{References:-}

1. Aristotle (1895). The Poetic of Aristotle (translated by Butcher, S. H). London: Macmillan Publishers.

2. Bell, C. (2002). Ritual Practice. New York: Oxford University Press.

3. Freytag, G. (1863). Die Technik des Dramas. German: German Press.

4. Gibbs, J. and Lindfors, B. (1993). Research on Wole Soyinka. Trenton, N J: African World Press.

5. Temple, J. G. and Honeck, R.P. (1999). Proverb Comprehension: The Primacy of Literal Meaning. J Psycholinguist Res, 28(1), 41-70.

6. Kwakwa, P. (1982). A Dance and Drama of the Gods: A Case Study (MA Thesis). University of Ghana.

7. La Fontaine, J. (1994). Initiation Ritual Drama and Secret Knowledge across the World: Evaluation Criteria and Critique Research Studies. In J. M. Morse, Critical Issues in Qualitative Research Method. London: Sage Press.

8. Makila, W. (1978). An outline of the History of Babukusu of western Kenya. Nairobi: Kenya Literature Bureau.

9. Mari, A. (2012). An Analysis of Repetition Patterns in the Hothouse and the Caretaker by Herold Pinter's (Master's Thesis). The University of Oslo.

10. Reams, J. (2015). Characterization in Fiction (PhD Thesis). Texas State University.

11. Rodney, W. (1980). How Europe Underdeveloped Africa. London: Bogle L'Ouverture Publications.

12. Simiyu, V. (1990). The Emergence of a Sub-nation. A History of Babukusu to 1990. Trans African Journal of History, 20(4), 125-144.

13. Turner, W. (1977). Symbols in African Ritual. In Symbolic Anthropology: A Reader in the Study of Symbols and Meanings. New York: Columbia University Press.

14. Wanyama, M.N. (2005). Form and Content of African Music: A Case Study of Bukusu Circumcision Music (PhD Thesis). University of Pretoria.

15. Wanyama, M. and Egesa, O. (2015). Ethonography and Ethono-Music of Babukusu Traditional Male Circumcision; Messaging, Symbolism and Rationale. The Journal on Babukusu Traditional Male Circumcision, 3(1), 6-18. 